\title{
BIENVENIDA
}

\section{Desacatos, una revista de su tiempo}

\author{
Alberto Aziz Nassif
}

$\mathrm{D}$ espués de ver las distintas etapas que ha tenido nuestra revista, puedo decir que se trata de una publicación que se encuentra en su mejor momento: es reconocida y su prestigio es creciente. Desacatos marcha como un tren de alta velocidad al que tenemos que subirnos. Sin duda, la revista del Centro de Investigaciones y Estudios Superiores en Antropología Social (CIESAs) ha alcanzado reconocimiento en el medio académico nacional e internacional. Esta publicación expresa el trabajo de una red de comunidades académicas que publican el resultado de su trabajo de investigación. Con estándares de alta calidad, Desacatos llega a su número 44 , muestra su juventud y al mismo tiempo su fortaleza. Cercana a cumplir 15 años de existencia, la revista cuenta con un equipo de trabajo especializado, con un Comité editorial que se encarga de vigilar la calidad y llevar cada número a buen puerto, y con un Cuerpo académico asesor de primer nivel.

Jorge Alonso logró hacer de la revista un espacio de las comunidades del ciesas. Además de darle estabilidad y de incorporarla a 16 índices importantes - nacionales e internacionales - ahora, al fin, Desacatos cuenta con una página electrónica más amable y útil para las búsquedas, la difusión y la interconectividad. La revista está ya en su versión electrónica en el formato Open Journal System (ojs) y poco a poco se subirán todos los números. Queda un legado de objetivos cumplidos y resultados visibles. Será un reto estar a la altura de la marca que deja quien fue su director casi diez años.

La calidad de Desacatos es una expresión directa de los buenos resultados que se obtienen en el CIESAS y en las comunidades cercanas y lejanas que han decidido publicar en la revista. En cada número tratan problemas y dimensiones que tienen rigor académico y aportes significativos. Desacatos se ha convertido en un destacado medio para difundir las ciencias sociales y para debatir los problemas de nuestro tiempo. Su discurso fotográfico es una singularidad que rompe con el monólogo de las letras y establece un diálogo entre textos e imágenes. La revista está consolidada, pero consolidación no quiere decir congelamiento, porque estoy seguro de que Desacatos enfrentará nuevos desafíos, sobre todo en el campo de las redes sociales y las nuevas tecnologías, un universo en el que ya vive nuestra revista.

Quiero invitar a todas las comunidades del CIESAS a que mantengamos la revista en los mejores niveles porque seguirá siendo un espacio de los investigadores $y$, sin duda, también de otras comunidades que ya forman parte de esta publicación. El compromiso es académico y el horizonte está despejado. El trabajo editorial de una revista lo entiendo como un proceso colectivo, normado, pero lleno de creatividad; con el rigor del dictamen y la oportunidad de la difusión. Pluralidad de enfoques, multidisciplina y 
problemas complejos seguirán siendo marcas de la revista, máxime en un mundo global. El actual momento de las ciencias sociales ha entrado en una fase en donde los núcleos duros de las disciplinas se han desvanecido y se han fortalecido las fronteras y los acercamientos disciplinares, la antropología social convive con la sociología, la historia, la lingüística, la ciencia política, la geografía, la economía, y esa dinámica genera influencias, intercambios y nuevas miradas para el trabajo de investigación.
En las diferentes oportunidades que he tenido de participar en Desacatos, en su inicio para nombrarla y ponerla a caminar, después como parte de su Comité editorial, y en dos ocasiones en las que he coordinado números, he aprendido que la revista es un espacio generoso y creativo del oficio académico. Por todas estas razones he aceptado participar en la dirección editorial de la revista. Estoy seguro de que nuestros múltiples encuentros serán una oportunidad para seguir construyendo Desacatos. 